\title{
Molecular Mechanisms of Scleroderma and Fibrosis
}

\author{
Kocak A. ${ }^{1}$, Harmancı D. ${ }^{1}$, Birlik M. ${ }^{2},{ }^{1,3}$ Güner G. \\ ${ }^{1}$ Dokuz Eylul University, Institute of Health Sciences, Molecular Medicine Department, İzmir \\ ${ }^{2}$ Dokuz Eylul University, Faculty of Medicine, Department of Rheumatology, İzmir \\ ${ }^{3}$ İzmir University of Economics, Medicine Faculty, Medical Biochemistry Department, İzmir, Turkey
}

\begin{abstract}
Scleroderma is a chronic autoimmune inflammatory disease with widespread fibrosis of the skin and internal organs. Scleroderma is characterized by vascular injury, immune activation, inflammation and fibrosis. However, controversies related with the pathogenesis of scleroderma are still existing. Moreover, scleroderma is the most unsuccessfully treated disease in the rheumatic disorders. Despite prominent advances in the treatments of scleroderma related renal crisis, interstitial lung fibrosis and pulmonary arterial hypertension, treatment of skin involvement still continues to be a problem. The molecular mechanism of fibrosis should be clarified for the development of new drugs and treatment.
\end{abstract}

Keywords: Scleroderma, Fibrosis, Treatment

\section{INTRODUCTION}

Systemic sclerosis or scleroderma is a disease that shows involvement in internal organs or on the skin characterized by fibrosis. Dermis thickening and uncontrolled extracellular matrix (ECM) increase are seen in this disease whose pathogenesis is not fully understood $(1,2)$.

Fibrosis may occur in all organs, but the first signs are usually seen on the skin. Fibrosis begins in the lower dermis with the involvement of subcutaneous fat tissue(2). There is not a certain treatment applied for Scleroderma yet.

\section{SCLERODERMA}

Scleroderma is an autoimmune disease characterized with fibrosis (1-2).Clinically, systemic sclerosis is a heterogeneous disease with different sub-groups characterized by visceral involvement, measured by the presence of different antibodies $(3,4)$.

It is a rare disease with a prevalence ranging from 50 to 300 in a million. As in many autoimmune diseases, women are under a higher risk than men (4-6).

Scleroderma is not a genetic disease (7). Many molecular pathways play an active role in this diseases and the relationship of all these pathways between each other is highly complex (8-15). Studies have shown that the disease plays a role in relation to extracellular matrix (ECM) genes and genes related to autoimmunity (control of natural immunity, functions such as the activation of macrophages and Tcells), as other immunological diseases.

The disease is most commonly seen at age 30-50 and the ratio of female to male is 8/1(16).In the United States, the incidence and prevalence of Scleroderma in the adult population were reported to be 19.3 and 242 in a million, respectively (5).

Although current treatment approaches control some findings of scleroderma, there is no internationally accepted treatment protocol for scleroderma (17). Scleroderma treatment should be regulated according to the organ systems involved and the severity of clinical findings. For this reason, when treatment is planned, the patients should be carefully evaluated in terms of organ system involvements. Currently, there is no approved basic effect drug that may be used in established fibrosis treatment (18). Corticosteroids are not effective on the disease progression(18). Additionally, corticosteroids may activate renal crisis and immunosuppressives such as azathioprine, chlorambucil and 5-fluorouracil have been found to be ineffective in scleroderma $(19,20)$. The effect of Dpenicillamine, which has been used for many years, is controversial (21). Target pathways and 
molecular mechanisms are quite important in the development of new treatments with studies that have been made in recent years. Clarifying the molecular pathways of fibrosis and targeted treatments are quite important parts of scleroderma.

\section{FIBROSIS MECHANISM IN SCLERODERMA}

Fibrosis is the main mechanism in scleroderma. Fibrosis may occur in all organs but first signs are usually seen on the skin.) Fibrosis begins in the lower dermis with the involvement of subcutaneous fat tissue (2). The formation of fibrosis begins with the accumulation of active fibroblast cells and produced ECM structures (22). It is clear that excessive accumulation of ECM components with de novo synthesis is an important factor (23).

Thus, it contributes to the degradation and remodelling of ECM with fibrotic reaction (24). Figure 1 shows the environmental factors and pathogenesis that play a role in the development of fibrosis. More recently, it has been shown that macromolecule organization and component of ECM are altered by controlling tissue stiffness, growth factors and activation of cytokines (25-28).

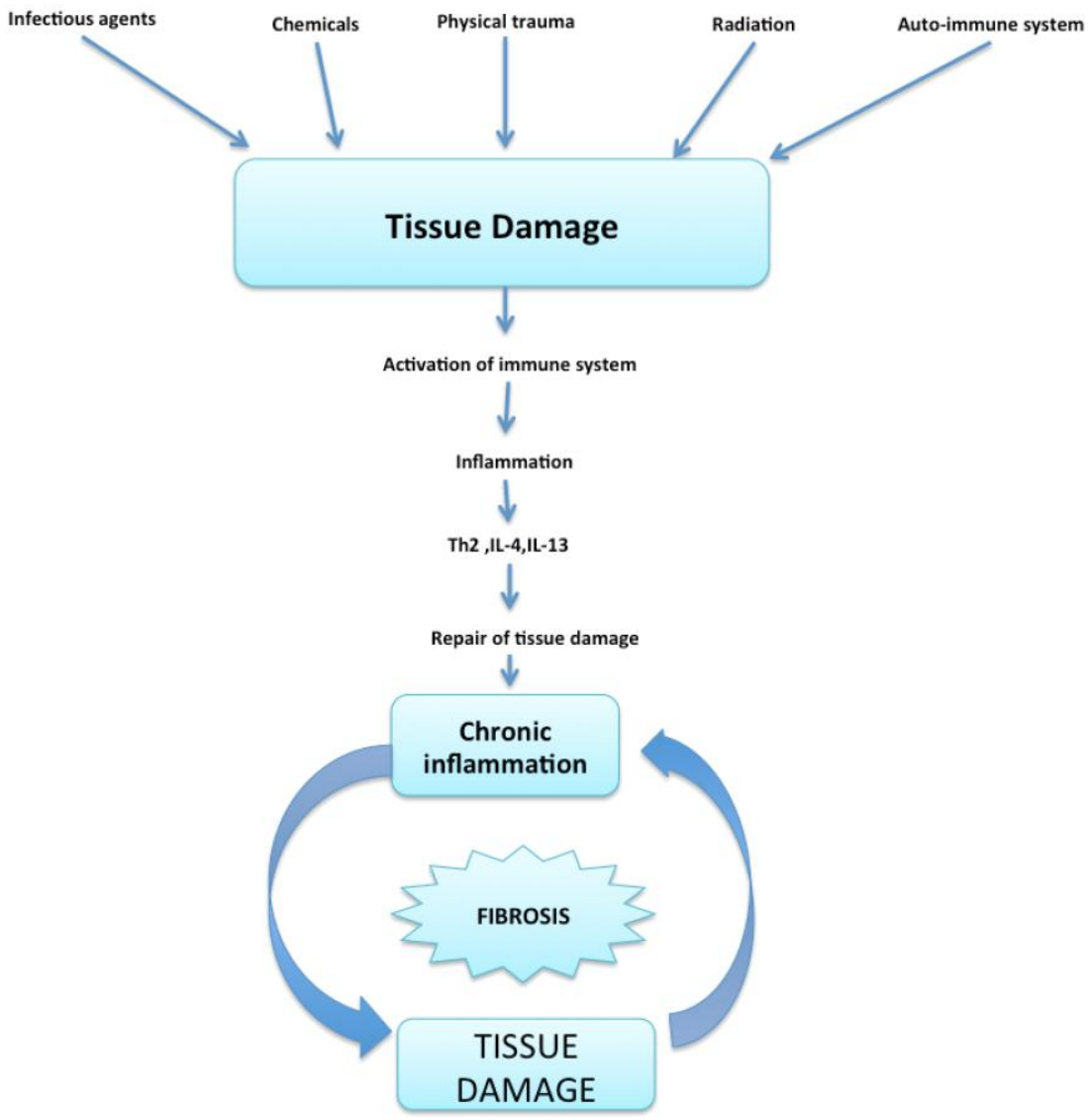

Figure1. Fibrosis Pathogenesis

Fibroblasts that go through many steps, by the activity of TGF- $\beta$, CTGF, PDGF and other factors, transform into ( $\alpha$-SMA) myofibroblasts characterized by $\alpha$-smooth muscle actin $(25,26)$. This process is completely a TGF $\beta$ - dependent process. By this time, many studies have been done on pathways related to fibroblast activation. Animal experiments have been done on scleroderma and studies are continuing for this pathway (29). It has been shown that in scleroderma fibroblasts, the mitogenic activity of PDGF receptors, a path way, is more sensitive. Also the activation of TGF- $\beta$ receptors has been shown (38). The inferior pathways of TGF- $\beta$ continue as Smad2/3 and Smad4. Smad 7, an endogenous inhibitor represses this pathway $(25,31)$. Some studies have shown that Wnt, Notch, Hedgehog, JAK-Stat pathways play an important role in fibrotic process $(32,33)$. With these findings, the role of Wnt $\beta$-katenin pathway in mesenchymal cells were supported with systematic analyses $(34,35)$.In vitro experiments have shown the role of Wnt pathway`s collagen modelling, movement and reproduction of normal fibroblasts(34). Scleroderma is a disease characterized with immune system deficiency. Many mechanisms responsible from the immune system such as Th1, Th2 (auxiliary $\mathrm{T}$ cell responses) play a role (36-38).Figure 2 shows some cytokines related to systemic sclerosis and fibrosis, cellular sources of growth factors and biological activities (36-48). 
Molecular Mechanisms of Scleroderma and Fibrosis

Table1. Cytokines and growth factors functionary in fibrosis (36-48)

\begin{tabular}{|c|c|c|}
\hline $\begin{array}{l}\text { Cytokines and } \\
\text { Growth factors }\end{array}$ & Cellular Source & Biological Activity \\
\hline $\mathrm{IFN} \gamma$ & $\begin{array}{c}\text { Lymphocytes, dendritic and NK } \\
\text { cells }(38,39,41,47)\end{array}$ & $\begin{array}{l}\text { Th1 differentiation, activation of } \\
\text { B cells }\end{array}$ \\
\hline $\mathrm{TNF} \alpha$ & $\begin{array}{l}\text { Macrophages, dermal mast cells and } \\
\text { keratinocytes }(36,37,38,44,46)\end{array}$ & $\begin{array}{l}\text { Neutrophil and lymphocyte } \\
\text { healing, pro-inflammatory and } \\
\text { Pro-apoptotic response }\end{array}$ \\
\hline Interlökin-1 & $\begin{array}{c}\text { Monocytes, macrophages, dendritic and } \\
\text { endothelial } \\
\text { cells }(38,39,46) \\
\end{array}$ & $\begin{array}{c}\text { Proinflammatory, interleukin-6 } \\
\text { construction, PDGF } \alpha \text { Th } 1 \text { and } \\
\text { Th17 differentiation } \\
\end{array}$ \\
\hline Interlökin-2 & T lymphocytes $(38,44,46,47)$ & $\begin{array}{c}\text { Stimulation of NK and CD8 + } \\
\text { cells }\end{array}$ \\
\hline Interlökin-5 & Th2 and mast cells $(36,37,38,41,47)$ & differentiation of B cells \\
\hline Interlökin-6 & $\begin{array}{l}\text { Fibroblasts, Th2 cells, macrophages, epithelial } \\
\text { cells }(38,39,41,42,43)\end{array}$ & $\begin{array}{c}\text { Collagen synthesis and inhibition } \\
\text { of collagenase synthesis }\end{array}$ \\
\hline Interlökin-10 & $\begin{array}{c}\text { Activated B cells and } \\
\text { monocytes }(38,40,41,43,44)\end{array}$ & $\begin{array}{l}\text { Collagen synthesis and } \\
\text { Immune response }\end{array}$ \\
\hline Interlökin-13 & $\begin{array}{l}\text { Th2 cells, NK and } \\
\text { Mast } \\
\text { Cells }(36,37,38,41)\end{array}$ & $\begin{array}{c}\text { B cell proliferation and } \\
\text { differentiation, anti-inflammatory } \\
\text { response and } \\
\text { Fibrosis }\end{array}$ \\
\hline TGF- $\beta$ & $\begin{array}{c}\text { Keratinocytes, Macrophages, } \\
\text { Fibroblasts, T and B cells, platelets and } \\
\text { endothelial } \\
\text { cells } \\
(36,38,39,40,41,44,46,47,48)\end{array}$ & $\begin{array}{c}\text { Expression of fibroblast } \\
\text { proliferation stimulation, } \\
\text { expression of PDGF and TGF } \beta \text {, } \\
\text { production of CTGF and } \\
\text { endothelin-1, } \\
\text { Stimulation of collagen, } \\
\text { fibronectin, proteoglycans, and } \\
\text { TIMP (ECM destruction } \\
\text { inhibitors) synthesis } \\
\end{array}$ \\
\hline $\begin{array}{l}\text { CTGF (connective } \\
\text { tissue growth } \\
\text { factor) }\end{array}$ & $\begin{array}{c}\text { Fibroblasts,Endothelial cells, smooth muscle } \\
\text { cells } \\
\text { (Induced by TGF } \beta \text {, IL-4, and } \\
\text { VEGF). }(38,39,39,48)\end{array}$ & $\begin{array}{l}\text { Fibroblast proliferation, } \\
\text { chemotaxis of fibroblasts in ECM } \\
\text { production }\end{array}$ \\
\hline PDGF & $\begin{array}{l}\text { Platelets, macrophages, fibroblasts, endothelial } \\
\text { cells } \\
(38,39,40,46,47,48)\end{array}$ & $\begin{array}{c}\text { Movement of fibroblasts, } \\
\text { collagen, fibronectin and } \\
\text { proteoglycan synthesis, TGF } \beta \text { and } \\
\text { IL-6 stimulation }\end{array}$ \\
\hline Endothelin-1 & Endothelial cells $(38,39)$ & $\begin{array}{l}\text { Fibroblast proliferation and } \\
\text { collagen synthesis }\end{array}$ \\
\hline
\end{tabular}

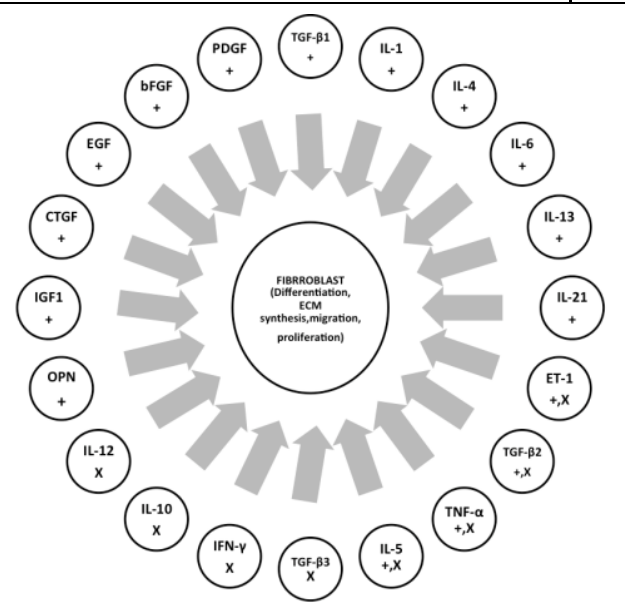

Figure3. Molecules involved in fibrosis

'+'marked molecules $\rightarrow$ Fibrosis-activating molecules, ' $X$ 'marked molecules $\rightarrow$ Molecules involved in the inhibition of fibrosis,

${ }^{+}+, \boldsymbol{X}$ 'marked molecules $\rightarrow$ Molecules acts as both an activator and an inhibitor in the mechanism of fibrosis formation. 


\section{COLLAGEN INCREASE AND BIOSYNTHESIS IN FIBROSIS}

ECM and collagen increase is the most characterized feature of fibrosis which is the formation mechanism of scleroderma. Collagen proteins on the skin show a completely dispersed arrangement, forming a reticular structure. The covalent bonds between fibrils strengthen this structure. After being produced in the ribosomes of fibroblasts, collagen passes through endoplasmic reticulum and takes the helix form. Helix formation occurs as a result of prolin remaining from hydrolysis and hydroxyproline and hydroxylation of lysine.

Oxygen and ascorbic acid are needed for hydroxylation. This formation which takes the structure of helix is called procollagen $(49,50)$.

Procollagen exuded out of the cell from fibroblasts, is converted into a structure called tropocollagen by procollagen peptidase enzyme. Tropocollagen molecules synthesized inside the cell form the major components of collagen fibrils. Tropocollagen is a protein molecule whose molecular weight is about 300,000 daltons. It consists of 3 polypeptide chains of the same size that are made of 1000 amino acids. Collagen fibril ingenerates from 2 identical chains called $\alpha-1$ and a third bond called $\alpha-2$ coming together and forming a common helix structure. The collagen protein has $35 \%$ glycine and $11 \%$ alanine in its structure. Unlike other proteins, collagen contains $12 \%$ proline and $9 \%$ hydroxyproline. These amino acids are rarely found in other proteins. Glycine proline-hydroxyproline amino acids repeat continuously in the collagen structure.

Tropocollagen molecules come together in vivo conditions to form a left-handed Helix. In vitro conditions, it takes a quite long time for $\alpha-1$ and $\alpha-2$ bonds to form a triple Helix.Therefore, the percentage of this structure is lower compare to total tropocollagene in the environment. (50). Collagen fibrils have long, crystal and filamentous structures that provide resistance to tissues (51). The fibrils are packed with connective tissue cells between them to provide support to the tissues. The bonds forming the collagen molecules contain an $\mathrm{NH} 2(\alpha)$ and a $\mathrm{COOH}-(\beta)$ tip. The formation of mature collagen fibrils occurs when procollagen molecules, including $\alpha$ and $\beta$ ends, are attached to each other.The procollagen molecules attached end to end have asymmetric tips (51). $\alpha$ tips are long and thin, $\beta$ tips are shorter and thick. These fibril tips are first defined in the tendon tissue, then in the cornea and dermis $(52,53,54)$.In scleroderma there is a direct proportion between the increase in collagen and the progression of the disease (55).

\section{Conclusion}

With the new studies, the molecular pathways in the fibrosis process of Scleroderma are becoming more prominent. It may be effective in treatment or in preventing fibrosis when a specific inhibition mechanism is revealed in ECM synthesis or in the molecular mechanism of sclerotic lesion formation (38).

In the clinic, there is a need to develop new strategies and therapeutic agents for the treatment of scleroderma.

\section{REFERENCES}

[1] Varga, J. 2012. 15. Scleroderma - from pathogenesis to comprehensive management. Varga, J., Denton, C., Wigley, F.M./Denton C. New York: Springer.

[2] Gabrielli, A., Avvedimento, E.V., Krieg, T. 2009. "Scleroderma", N Engl J Med, 360, 19892003.

[3] Van den Hoogen, F., Khanna, D., Fransen,J., Johnson, S.R., Baron, M., Tyndall, A., MatucciCerinic, M., Naden, R.P., Medsger, T.A. Jr, Carreira, P.E., et al. 2013. "2013 classification criteria for systemic sclerosis: an American College of Rheumatology/European League against Rheumatism collaborative initiative", Arthritis Rheum, 65, 2737- 2747.

[4] Hunzelmann, N., Genth, E., Krieg, T., Lehmacher, W., Melchers, I., Meurer, M., Moinzadeh, P., Muller-Ladner, U., Pfeiffer, C., Riemekasten, G. et al. 2008. "The registry of the German Network for Systemic Scleroderma: frequency of disease subsets and patterns of organ involvement", Rheumatology (Oxford), 47, 1185-1192.

[5] Mayes, M.D., Lacey, J.V. Jr, Beebe-Dimmer, J., Gillespie, B.W., Cooper, B., Laing, T.J., Schottenfeld, D. 2003. "Prevalence, incidence, survival, and disease characteristics of systemic sclerosis in a large US population", Arthritis Rheum, 48, 2246-2255. 
[6] Allanore, Y., Dieude, P., Boileau, C. 2010. "Genetic background of systemic sclerosis: autoimmune genes take centre stage", Rheumatology (Oxford), 49, 203-210.

[7] Feghali-Bostwick, C., Medsger, T.A. Jr, Wright, T.M. 2003. "Analysis of systemic sclerosis in twins reveals low concordance for disease and high concordance for the presence of antinuclear antibodies", Arthritis Rheum, 48, 1956-1963.

[8] Zhou, X., Tan, F.K., Wang, N., Xiong, M., Maghidman, S., Reveille, J.D., Milewicz, D.M., Chakraborty, R., Arnett, F.C. 2003. "Genome-wide association study for regions of systemic sclerosis susceptibility in a Choctaw Indian population with high disease prevalence" Arthritis Rheum, 48, 2585-2592.

[9] Dieude, P., Guedj, M., Wipff, J., Avouac, J., Fajardy, I., Diot, E., Granel, B., Sibilia, J., Cabane, J., Mouthon, L. et al. 2009.."Association between the IRF5 rs2004640 functional polymorphism and systemic sclerosis: a new perspective for pulmonary fibrosis" Arthritis Rheum, 60, 225233.

[10] Rueda, B., Gourh, P., Broen, J., Agarwal, S.K., Simeon, C., Ortego-Centeno, N., Vonk, M.C., Coenen, M., Riemekasten, G., Hunzelmann, N. et al. 2010. "BANK1 functional variants are associated with susceptibility to diffuse systemic sclerosis in Caucasians", Ann Rheum Dis, 69, 700-705.

[11] Tan, F.K., Wang, N., Kuwana, M., Chakraborty, R., Bona, C.A., Milewicz, D.M., Arnett, F.C. 2001. "Association of fibrillin 1 single-nucleotide polymorphism haplotypes with systemic sclerosis in Choctaw and Japanese populations", Arthritis Rheum, 44, 893-901.

[12] Fonseca, C., Lindahl, G.E., Ponticos, M., Sestini, P., Renzoni, E.A., Holmes, A.M., Spagnolo, P., Pantelidis, P., Leoni, P., McHugh, N. et al. 2007. "A polymorphism in the CTGF promoter region associated with systemic sclerosis", N Engl J Med, 357, 1210-1220.

[13] Tan, F.K., Zhou, X., Mayes, M.D., Gourh, P., Guo, X., Marcum, C., Jin, L., Arnett, F.C. Jr. 2006. "Signatures of differentially regulated interferon gene expression and vasculotrophism in the peripheral blood cells of systemic sclerosis patients", Rheumatology (Oxford), 45, 694-702.

[14] York, M.R., Nagai, T., Mangini, A.J., Lemaire, R., van Seventer, J.M., Lafyatis, R. 2007. “A macrophage marker, Siglec-1, is increased on circulating monocytes in patients with systemic sclerosis and induced by type I interferons and toll-like receptor agonists", Arthritis Rheum, 56, 1010-1020.

[15] Christmann, R.B., Sampaio-Barros, P., Stifano, G., Borges, C.L., de Carvalho, C.R., Kairalla, R., Parra, E.R., Spira, A., Simms, R., Capellozzi, V.L. et al. 2014. "Association of Interferon- and transforming growth factor beta-regulated genes and macrophage activation with systemic sclerosis-related progressive lung fibrosis", Arthritis Rheumatol, 66, 714-725.

[16] Mayes MD. Scleroderma epidemiology. Rheum Dis Clin North Am 1996;22:751-764.

[17] Kowal-Bielecka O, Landewé R, Avouac J, Chwiesko S, Miniati I, Czirjak L, et al. EULAR recommendations for the treatment of systemic sclerosis: a report from the EULAR Scleroderma Trials and Research group (EUSTAR). Ann Rheum Dis 2009;68:620-628.

[18] Czirják L. Practical approach to the therapy of systemic sclerosis. Z Rheumatol 2004;63:451456.

[19] Casas JA, Saway PA, Villarreal I, Nolte C, Menajovsky BL, Escudero EE, et al. fluorouracil in the treatment of scleroderma: a randomised, double blind, placebo controlled international collaborative study. Ann Rheum Dis 1990;49:926-928.

[20] 21. Furst DE, Clements PJ, Hillis S, Lachenbruch PA, Miller BL, Sterz MG, Paulus HE. Immunosuppression with chlorambucil, versus placebo, for scleroderma. Results of a three-year, parallel, randomized, double-blind study. Arthritis Rheum 1989;32:584-593.

[21] 22. Clements PJ, Furst DE, Wong WK, Mayes M, White B, Wigley F, et al. High-dose versus lowdose D-penicillamine in early diffuse systemic sclerosis: analysis of a two-year, doubleblind, randomized, controlled clinical trial. Arthritis Rheum 1999;42:1194-1203.

[22] Perlish, J.S., Lemlich, G., Fleischmajer, R. 1988. "Identification of collagen fibrils in scleroderma skin", J Invest Dermatol, 90, 48-54.

[23] LeRoy, E.C. 1974. "Increased collagen synthesis by scleroderma skin fibroblasts in vitro: a possible defect in the regulation or activation of the scleroderma fibroblast", J Clin Invest, 54, 880-889. 
[24] Nagase, H., Visse, R., Murphy, G. 2006. "Structure and function of matrix metalloproteinases and TIMPs", Cardiovasc Res, 69, 562-573.

[25] Abraham, D.J., Krieg, T., Distler, J., Distler, O. 2009. "Overview of pathogenesis of systemic sclerosis", Rheumatology (Oxford), 48, 3-7.

[26] Gerber, E.E., Gallo, E.M., Fontana, S.C., Davis, E.C., Wigley, F.M., Huso, D.L., Dietz, H.C. 2013. "Integrin-modulating therapy prevents fibrosis and autoimmunity in mouse models of scleroderma", Nature, 503, 126-130.

[27] Agarwal, P., Schulz, J.N., Blumbach, K., Andreasson, K., Heinegard, D., Paulsson, M., Mauch, C., Eming, S.A., Eckes, B., Krieg, T. 2013. "Enhanced deposition of cartilage oligomeric matrix protein is a common feature in fibrotic skin pathologies", J Int Soc Matrix Biol 32, 325-331.

[28] Hynes, R.O. 2009. "The extracellular matrix: not just pretty fibrils", Science, 326, 1216-1219.

[29] Avouac, J., Elhai, M., Allanore, Y. 2013. "Experimental models of dermal fibrosis and systemic sclerosis", Joint Bone Spine revue du rhumatisme, 80, 23-28.

[30] Kawakami, T., Ihn, H., Xu, W., Smith, E., LeRoy, C., Trojanowska, M. 1998. "Increased expression of TGF-beta receptors by scleroderma fibroblasts: evidence for contribution of autocrine TGF-beta signaling to scleroderma phenotype", J Invest Dermatol, 110, 47-51.

[31] Varga, J., Abraham, D. 2007. "Systemic sclerosis: a prototypic multisystem fibrotic disorder", J Clin Invest, 117, 557-567.

[32] Akhmetshina, A., Palumbo, K., Dees, C., Bergmann, C., Venalis, P., Zerr, P., Horn, A., Kireva, T., Beyer, C., Zwerina, J. et al. 2012. "Activation of canonical Wnt signalling is required for TGF-beta-mediated fibrosis”, Nat Commun, 3, 735.

[33] Beyer, C., Distler, J.H. 2013. "Morphogen pathways in systemic sclerosis", Curr Rheumatol Rep, 15, 299.

[34] Wei, J., Fang, F., Lam, A.P., Sargent, J.L., Hamburg, E., Hinchcliff, M.E., Gottardi, C.J., Atit, R., Whitfield, M.L., Varga, J. 2012. "Wnt/beta-catenin signaling is hyperactivated in systemic sclerosis and induces Smad-dependent fibrotic responses in mesenchymal cells", Arthritis Rheum, 64,2734-2745.

[35] Konigshoff, M., Kramer, M., Balsara, N., Wilhelm, J., Amarie, O.V., Jahn, A., Rose, F., Fink, L., Seeger, W., Schaefer, L. et al. 2009. "WNT1- inducible signaling protein-1 mediates pulmonary fibrosis in mice and is upregulated in humans with idiopathic pulmonary fibrosis", J Clin Invest, 119, 772-787.

[36] Antsiferova, M., Martin, C., Huber, M., Feyerabend, T.B., Forster, A., Hartmann, K., Rodewald, H.R., Hohl, D., Werner, S. 2013. "Mast cells are dispensable for normal and activin-promoted wound healing and skin carcinogenesis", J Immunol, 191, 6147-6155.

[37] Willenborg, S., Eckes, B., Brinckmann, J., Krieg, T., Waisman, A., Hartmann, K., Roers, A., Eming, S.A. 2014. "Genetic ablation of mast cells redefines the role of mast cells in skin wound healing and bleomycin-induced fibrosis", J Invest Dermatol, 134, 2005-1015.

[38] Wynn, T.A., Ramalingam, T.R. 2012. "Mechanisms of fibrosis: therapeutic translation for fibrotic disease", Nat Med, 18,1028-1040.

[39] Whitfield, M.L., Finlay, D.R., Murray, J.I., Troyanskaya, O.G., Chi, J.T., Pergamenschikov, A., McCalmont, T.H., Brown, P.O., Botstein, D., Connolly, M.K. 2003. "Systemic and cell typespecific gene expression patterns in scleroderma skin", Proc Natl Acad Sci USA, 100, 1231912324.

[40] Whitfield, M.L. 2014. "Editorial: plasma and B cell gene signatures: quantitative targeting and monitoring of B cell-depleting therapies in autoimmune diseases in the genomic era", Arthritis Rheumatol, 66, 10-14.

[41] Yoshizaki, A., Iwata, Y., Komura, K., Ogawa, F., Hara, T., Muroi, E., Takenaka, M., Shimizu, K., Hasegawa, M., Fujimoto, M. et al. 2008. "CD19 regulates skin and lung fibrosis via Toll-like receptor signaling in a model of bleomycin-induced scleroderma", Am J Pathol, 172, 1650-1663.

[42] van Laar, J.M. 2010. "B-cell depletion with rituximab: a promising treatment for diffuse cutaneous systemic sclerosis", Arthritis Res Ther, 12, 112-113.

[43] Jordan, S., Distler, J.H., Maurer, B., Huscher, D., van Laar, J.M., Allanore, Y., Distler, O. 2014. "Effects and safety of rituximab in systemic sclerosis: an analysis from the European Scleroderma Trial and Research (EUSTAR) group", Ann Rheum Dis, 0, 1-7. 
[44] Lafyatis, R., Kissin, E., York, M., Farina, G., Viger, K., Fritzler, M.J., Merkel, P.A., Simms, R.W. 2009. "B cell depletion with rituximab in patients with diffuse cutaneous systemic sclerosis", Arthritis Rheum, 60, 578-583.

[45] Daoussis, D., Liossis, S.N., Tsamandas, A.C., Kalogeropoulou, C., Kazantzi, A., Sirinian, C., Karampetsou, M., Yiannopoulos, G., Andonopoulos, A.P. 2010. "Experience with rituximab in scleroder- ma: results from a 1-year, proof-of-principle study", Rheumatology (Oxford), 49, 271-280.

[46] Bosello, S., De Santis, M., Lama, G., Spano, C., Angelucci, C., Tolusso, B., Sica, G., Ferraccioli, G. 2010. "B cell depletion in diffuse progressive systemic sclerosis: safety, skin score modification and IL-6 modulation in an up to thirty-six months follow-up open-label trial", Arthritis Res ther, 12, R54.

[47] Smith, V., Piette, Y., van Praet, J.T., Decuman, S., Deschepper, E., Elewaut, D., De Keyser, F. 2013. "Two-year results of an open pilot study of a 2-treatment course with rituximab in patients with early systemic sclerosis with diffuse skin involvement", J Rheumatol, 40, 52-57.

[48] Smith, V., Van Praet, J.T., Vandooren, B., Van der Cruyssen, B., Naeyaert, J.M., Decuman, S., Elewaut, D., De Keyser, F. 2010. "Rituximab in diffuse cutaneous systemic sclerosis: an openlabel clinical and histopathological study", Ann Rheum Dis, 69, 193-197.

[49] Stadelmann, W.K., Digenis, A.G., Tobin, G.R. 1998. "Physiology and healing dynamics of chronic cutaneous wounds", Surg., 176 (2): 26-38.

[50] Diegelmann, R.F., 2001. “Collagen metabolism”, Wounds, 13 (5): 177-182.

[51] Birk, D. E., Trelstad, R. L., 1986. "Extracellular compartments in tendon morphogenesis: collagen fibril, bundle, and macroaggregate formation", In The Journal of Cell Biology, 103: 231-240.

[52] Holmes, D. F., Lowe, M. P., Chapman, J. A., 1994. "Characterization of collagen fibril segments from chicken embryo cornea, dermis and tendon", J. Mol. Biol., 235: 80-83.

[53] Birk, D. E., Nurminskaya, M. V., Zycband, E. I., 1995. "Collagen fibrillogenesis in situ: fibril segments undergo post-depositional modification resulting in linear and lateral growth during matrix development”, Dev. Dyn., 202: 229-243.

[54] Kadler, K. E., Holmes, D. F., Trotter, J. A., Chapman, J. A., 1996. "Collagen fibril formation", Biochem. J., 316: 1-11.

[55] Birk, D. A., Zycband, E. I., Woodruff, S., Winkelmann, D.A., Trelstad R., 1997. "Collagen fibrillogenesis in situ: fibril segments become long fibrils as the developing tendon matures", Devel. Dyna., 208: 291-298. 